УДК 349.2

DOI https://doi.org/10.32844/2618-1258.2019.5-2.19

СОРОКА В.А.

\title{
ХАРАКТЕРИСТИКА ЗМІСТУ ЗВІЛЬНЕННЯ ЗА ПОРУШЕННЯ ТРУДОВОЇ ДИСЦИПЛІНИ ЯК ДИСЦИПЛІНАРНОЇ САНКЦІї
}

У статті визначено поняття звільнення за порушення трудової дисципліни як дисциплінарної санкції. Охарактеризовано особливості змісту звільнення за порушення трудової дисципліни як дисциплінарну санкцію. Окреслено сутність кожної з особливостей. Визначено, що обов'язковість зазначення підстави для звільнення, окрім власне виконання інформаційної функції, також посилює дію каральної та запобіжної функції, оскільки має безпосередній вплив не лише на конкретні правовідносини, а й на ті, в які працівник вступатиме в майбутньому. Шкода трудовій репутації працівника, безсумнівно, матиме вплив на його подальші спроби працевлаштуватись, а отже, вона безсумнівно є більшою, аніж шкода, завдана безпосередньо одностороннім розірванням трудового договору з ініціативи роботодавця. Тому таке звільнення має морально-виховний вплив, у тому числі й на інших працівників, оскільки вони на конкретному прикладі можуть переконатись у негативних наслідках учинення дисциплінарних проступків. 3'ясовано, що обрання дисциплінарної санкції у вигляді звільнення за порушення трудової дисципліни потребує від роботодавця всебічного з'ясування обставин, за яких було допущено порушення працівником установлення ступеня вини в його діяннях та причин, які послугували вчиненню проступку. Важливу роль відіграє ретельний аналіз усіх обставин, пов'язаних із порушенням працівником правил трудової дисципліни. при цьому враховуються не лише об'єктивні обставини, пов'язані із самим дисциплінарним проступком, а й суб'єктивні фактори, які мають вияв в аналізі особи працівника, притягнутого до відповідальності. Дослідження норм, які врегульовують накладення дисциплінарних санкцій на працівника, засвідчило, що ними не встановлено вказівки на співвідношення міри вини працівника та захід дисциплінарного стягнення. Тож застосування санкцій звільнення працівника значною мірою залежить від особи, наділеної повноваженнями дисциплінарної влади. Наголошено, що серед усіх можливих у вітчизняному праві засобів доказування щодо дисциплінарних справ законодавець звернув увагу саме на пояснення порушника, що підтверджує його особливе значення для подальшого прийняття рішення щодо звільнення працівника.

Ключові слова: звільнення працівника, порушення трудової дисципліни, дисциплінарна санкція, роботодавецьь, праця.

The article the notion of dismissal for violation of labour discipline as disciplinary sanction is defined. The peculiarities of the dismissal for violations of labour discipline as disciplinary sanction are described. The essence of each of the features is determined. It is determined that the obligation to state the grounds for dismissal, in addition to the proper performance of the information function, also enhances the effect of the punitive and preventive function, since it has a direct impact not only on specific relationships, but also on those in which the employee will enter in the future. Damage to an employee's working reputation will undoubtedly affect his further attempts to find a job, and therefore it is undoubtedly greater than the damage directly caused by an unilateral termination of the employment contract at the initiative of employer. Therefore, such dismissal has a moral and educational impact, including on other employees, as they can be convinced by the concrete example of the negative consequences of committing disciplinary offenses. It has been found that the choice of disciplinary sanction in the form of

(C) COPOKA B.A. 
dismissal for violation of labour discipline requires employer to thoroughly find out the circumstances under which the employee was violated, to establish the degree of guilt in his actions and the reasons that served the wrongdoing. An important role is played by a careful analysis of all the circumstances related to the employee's violation of the rules of labour discipline, taking into account not only the objective circumstances associated with the disciplinary offense itself, but also subjective factors that have manifested in the analysis of the employee's personality prosecuted. The study of the rules governing the imposition of disciplinary sanctions on an employee showed that they did not establish instructions on the correlation between the degree of guilt of the employee and the measure of disciplinary punishment. Therefore, the application of sanctions for dismissal of a worker depends to a large extent on a person empowered with disciplinary authority. It was emphasized that among all possible means of proof in the domestic law, the legislator on disciplinary cases paid attention precisely to the explanation of the offender, which confirms his special importance for the subsequent decision to dismiss the employee.

Key words: dismissal of an employee, violation of labour discipline, disciplinary sanction, employer, labour.

Вступ. Звільнення за порушення трудової дисципліни як дисциплінарна санкція - це найбільш строга міра дисциплінарного впливу власника чи вповноваженого органу (або держави), яка зумовлює розірвання із працівником трудових відносин з урахуванням обставин справи та характеристики особи, на яку накладається санкція.

Дослідивши сутність звільнення за вчинення дисциплінарного проступку, зазначимо, що важливим постає аналіз цього питання як дисциплінарної санкції.

Серед науковців, які внесли найбільший вклад у дослідження розірвання трудових договорів з ініціативи роботодавця, варто назвати таких: О.С. Бондар, Т.В. Дубас, І.А. Іоннікова, Ю.В. Ісаєв, С.М. Козін, І.М. Кравченко, І.О. Кравченко, І.В. Лазор, Н.М. Пиж. Тим не менш, досі не було проведено детального аналізу специфіки змісту звільнення за порушення трудової дисципліни як дисциплінарної санкції, що й зумовлює актуальність тематики.

Постановка завдання. Метою статті є детальна характеристика змісту звільнення за порушення трудової дисципліни як дисциплінарної санкції.

Результати дослідження. Опосередкування означає вираження за допомогою чогонебудь іншого [1, с. 849]. Оскільки наявність функцій у дисциплінарній відповідальності, як і в будь-якого іншого виду відповідальності, $є$ неоднозначним у правовій доктрині нашої держави, логічним $\epsilon$ вираження цих функцій за допомогою ії активних елементів, одним із яких $є$ дисциплінарна санкція. Іншими словами, сутність цієї ознаки полягає в тому, що в умовах спірності та динамічності переліку функцій дисциплінарної відповідальності (причому деякі дослідники, такі як В.М. Горшенєв [2, с. 96], заперечують їх наявність узагалі) та їх переліку, функції $є$ притаманними саме дисциплінарним санкціям.

У науковій літературі відсутня єдина концепція виокремлення функцій дисциплінарної відповідальності. Наприклад, В.І. Щербина виділяє наступні функції дисциплінарної відповідальності: стимулюючу, виховну, відновлювальну, запобіжну та каральну [3, с. 296]. Проте з огляду на багатогранність категорії дисциплінарної відповідальності, такий перелік є дещо усіченим. Більш доцільною в цьому аспекті виглядає концепція, запропонована Т.М. Лежнєвою, щодо поділу функцій на дві групи: юридичні та соціальні. Відповідно, першу групу становлять каральна, охоронна та запобіжна функції. Друга група сформована з виховної та інформаційної функцій [4, с. 53]. Аналізуючи виділені функції в контексті звільнення працівника за порушення трудової дисципліни, зазначаємо, що навряд чи цій санкції притаманна регулятивна функція, оскільки ії дії не є спрямованими на врегулювання поведінки винної особи - це конкретна міра відповідальності за вчинений проступок. Також сумнівним є виділення виховної функції. Оскільки мова йде про найвищу міру покарання за порушення дисциплінарних норм, ії застосування має на меті каральний ефект за умов, коли інші види відповідальності не відповідатимуть сутності проступку. Отже, визначившись із переліком функцій дисциплінарної відповідальності, опосередкування яких здійснюється за допомогою дисциплінарних санкцій, перейдемо до аналізу звільнення судді за порушення трудової дисципліни через їх призму.

Звільнення відрізняється від інших видів дисциплінарних стягнень застосуванням винятково у випадках, передбачених законодавством за вчинення вичерпного переліку дисциплінарних проступків. Більше того, це найбільш несприятливий для правопорушника наслідок, який 
виявляється в односторонньому розірванні з ним трудових правовідносин. Звільнення має вплив у першу чергу на правове становище працівника, оскільки він утрачає можливість реалізації своїх здібностей до продуктивної і творчої праці та отримання за це матеріального забезпечення саме в цьому й полягає каральна функція звільнення як дисциплінарної санкції

Охоронна та запобіжна функції реалізовуються схожим чином. Охоронна функція полягає в захисті відповідних правовідносин шляхом унеможливлення подальших дисциплінарних порушень 3 боку працівника в майбутньому, тож її реалізація в даному конкретному випадку дійсно відбувається в порядку звільнення.

Щодо запобіжної функції, то її реалізація здійснюється не через мотивацію правопорушника до правомірної поведінки, а шляхом усунення самого правопорушника 3 конкретних правовідносин як потенційного порушника трудової дисципліни [4, с. 55]. Тобто звільнення працівника має на меті запобігання вчинення ним аналогічних дисциплінарних проступків у майбутньому, особливо за умови наявності передумов для цього.

Інформаційна функція дисциплінарної санкції звільнення має особливий вияв. Наприклад, T.М. Лежнєва зазначає, що особливість інформаційної функції звільнення полягає в повідомленні всіх потенційних роботодавців щодо факту, підстав та причин звільнення шляхом здійснення відповідного запису у трудовій книжці [4, с. 53]. Так, відповідно до пункту 2.25 Інструкції про порядок ведення трудових книжок працівників, записи про причини звільнення у трудовій книжці повинні провадитись у точній відповідності до формулювань чинного законодавства 3 посиланням на відповідну статтю, пункт закону [5]. Обов'язковість зазначення підстави для звільнення, окрім власне виконання інформаційної функції, також посилює дію каральної та запобіжної функцій, оскільки має безпосередній вплив не лише на конкретні правовідносини, а й на ті, в які працівник вступатиме в майбутньому. Шкода трудовій репутації працівника, безсумнівно, матиме вплив на його подальші спроби працевлаштуватись, а отже, вона безсумнівно є більшою, аніж шкода, завдана безпосередньо одностороннім розірванням трудового договору з ініціативи роботодавця. Тому таке звільнення має морально-виховний вплив, у тому числі й на інших працівників, оскільки вони на конкретному прикладі можуть переконатись у негативних наслідках учинення дисциплінарних проступків.

Перейдемо до наступної ознаки. Працівник при укладенні трудового договору наділяється правами на отримання заробітної плати, не нижчої від визначеної законом, реалізацію своїх здібностей до продуктивної і творчої праці, на підвищення трудової кваліфікації та інші права, встановлені законодавством [6; 7]. Очевидно, що внаслідок звільнення працівник позбавляється всіх зазначених прав, як й інших, характерних винятково для працюючих: права на страйк для захисту своїх економічних і соціальних інтересів, на відпочинок, на соціальний захист, що включає право на забезпечення їх у разі повної, часткової або тимчасової втрати працездатності, втрати годувальника, безробіття з незалежних від них обставин [7]. Зрозумілим є те, що у працівника залишається право на захист своїх прав у судовому порядку. Відповідно до норм законодавства про працю, у звільнених осіб є право на проведення розрахунку згідно зі статтями 116 та 117 Кодексу законів про працю України, тобто на виплату всіх сум, що належать йому від підприємства, установи, організації [6]. Проте основні права, пов'язані з реалізацією гарантованого Основним Законом права на працю, звільненою особою все ж утрачаються до моменту укладання наступного трудового договору.

Третьою ознакою є примусовий характер дисциплінарних санкцій. Оскільки звільнення працівника здійснюється за ініціативою роботодавця, а значить примусово, ознака примусового характеру дисциплінарних санкцій $є$ характерною для досліджуваного нами явища.

Остання ознака - некомпенсаційний та непоновлюючий характер дисциплінарних санкцій. Дисциплінарні санкції, окрім власне звільнення, мають на меті виховання та попередження повторення правопорушень у перспективі. Більше того, поновлення сторін у правах $є$ неможливим, відповідно санкція у вигляді звільнення $є$ вищою мірою покарання за умови вчинення особами дисциплінарних проступків у вигляді систематичного невиконання працівником без поважних причин трудових обов'язків, прогулу, нез'явлення на роботу протягом більш як чотирьох місяців підряд внаслідок тимчасової непрацездатності, вчинення за місцем роботи розкрадання (в тому числі дрібного) майна власника, встановленого вироком суду, який набрав законної сили, появи на роботі в нетверезому стані, у стані наркотичного або токсичного сп'яніння тощо.

Оскільки дисциплінарна відповідальність завжди пов'язується з невиконанням або неналежним виконанням працівником своїх трудових обов'язків, важливим є дослідження того, як саме відбувається накладення на порушника суддівської дисципліни несприятливих позбавлень, передбачених законодавством. 
Одна $з$ юридичних гарантій при звільненні працівника за порушення трудової дисципліни - чітке дотримання правил і порядку, встановлених законодавством. Оскільки даний вид відповідальності $є$ різновидом дисциплінарної санкції, у випадку його застосування мають бути дотримані правила й порядок, закріплені статтями 147-149 Кодексу законів про працю України [6]:

1) до працівника за кожне порушення трудової дисципліни може бути застосовано лише одне дисциплінарне стягнення. Іншими словами, неможливою є ситуація, за якої порушнику трудової дисципліни оголошується догана і в подальшому його звільнено з роботи за вчинення цього ж дисциплінарного проступку;

2) при обранні виду стягнення має враховуються: ступінь тяжкості вчиненого проступку, заподіяна ним шкода, обставини, за яких вчинено проступок, попередня робота працівника - це правило вже було частково охарактеризоване. Досліджуване положення позитивно впливає на співвідношення принципу стабільності трудових правовідносин та реагування роботодавця на вчинення дисциплінарних проступків, оскільки при виборі стягнення береться до уваги сама особистість працівника. Перед власником може постати проблема припинення трудових відносин із працівником, який має позитивний вплив на трудовий колектив та в цілому належно виконує трудові обов'язки. Саме тому законодавець надав повноваження щодо вибору виду стягнення роботодавцю;

3) до прийняття рішення про звільнення працівника роботодавець повинен вимагати від нього письмове пояснення: працівник зобов'язаний пояснити свій дисциплінарний проступок та причини, які спонукали його до вчинення порушення трудової дисципліни. Таке роз' яснення також має бути врахованим при обранні виду стягнення і є важливим фактором під час рішення щодо звільнення працівника за порушення трудової дисципліни;

4) звільнення працівника оформлюється наказом (розпорядженням), без наявності такого акта й попереднього ознайомлення з ним працівника вважається, що працівник продовжує виконувати свої обов'язки відповідно до трудового договору та не є звільненим за порушення трудової дисципліни;

5) дисциплінарні стягнення застосовуються органом, якому надано право приймати на роботу працівника. Звільнити працівника має право тільки визначене коло посадових осіб, наділених законом дисциплінарною владою, інші керівники процесу праці можуть мати дисциплінарні права винятково у випадку передачі частини своєї компетенції керівником відповідно до норм статуту чи правил трудового розпорядку.

Висновки. Отже, обрання дисциплінарної санкції у вигляді звільнення за порушення трудової дисципліни потребує від роботодавця всебічного з'ясування обставин, за яких було допущено порушення працівником, встановлення ступеня вини в його діях та причин, що послугували вчиненню проступку. Важливу роль відіграє ретельний аналіз усіх обставин, пов'язаних із порушенням працівником правил трудової дисципліни, причому враховуються не лише об'єктивні обставини, пов'язані із самим дисциплінарним проступком, а й суб'єктивні фактори, які мають вияв в аналізі особи працівника, притягнутого до відповідальності. Дослідження норм, які врегульовують накладення дисциплінарних санкцій на працівника, засвідчило, що ними не встановлено вказівки на співвідношення міри вини працівника та заходу дисциплінарного стягнення. Тож застосування санкцій звільнення працівника значною мірою залежить від особи, наділеної повноваженнями дисциплінарної влади.

Таким чином, першим етапом процесу звільнення працівника за порушення трудової дисципліни є всебічне та повне з'ясування обставин дисциплінарної справи для його правильного вирішення: пояснення порушника трудової дисципліни для встановлення вини працівника в дисциплінарному проступку, обставин, за яких проступок був скоєний, аналіз попередньої роботи порушника, його поведінки в колективі, особистісних якостей. Значення даного етапу полягає в тому, що під час його реалізації в порушника все ще залишається можливість уникнення вищої міри негативних наслідків. Зі своєї боку, у власника чи вповноваженого органу формується остаточне розуміння конкретного дисциплінарного проступку й покарання, яке повинне бути застосоване до порушника.

На підставі даних пояснень уповноважена особа робить висновок щодо вибору заходу стягнення, в нашому випадку щодо звільнення особи. На зазначеному етапі керівники остаточно вирішують, яке буде покарання. Разом із тим, відмова порушника від надання пояснень не слугує перешкодою для накладення стягнення. Керівник реалізує дисциплінарну владу за допомогою встановленої законом процедури, яка втілюється в стадіях охоронного правовідношення $[8$, c. 68$]$. Іншими словами, уповноважена особа зобов'язана вимагати в порушника трудової дис- 
ципліни пояснення та дати їм оцінку. У свою чергу, порушник зобов'язаний надати пояснення, хоча в разі відмови власник у будь-якому випадку реалізовує свої повноваження, закріплені нормами законодавства про працю, та накладає стягнення [6]. Звертаємо увагу на те, що серед усіх можливих у вітчизняному праві засобів доказування законодавець дисциплінарних справ звернув увагу саме на пояснення порушника, що підтверджує його особливе значення для подальшого рішення про звільнення працівника. Отже, прийняття компетентною особою чи органом рішення про застосування санкції у вигляді звільнення за порушення трудової дисципліни зумовлює перехід до другого етапу даного процесу - оформлення звільнення.

Згідно із пунктом 4 статті 149 Кодексу законів про працю України, стягнення оголошуються в наказі (розпорядженні) й повідомляються працівникові під розписку [6]. Очевидно, що необхідність повідомлення працівника про звільнення та обов'язок його оформлення є наданням працівнику можливості оскарження рішення роботодавця. Після того. Як працівник погодився 3 таким фактом, дисциплінарна санкція у вигляді стягнення має бути занесена у трудову книжку та записана в точній відповідності з формулюваннями чинного законодавства та 3 посиланням на відповідну статтю, пункт закону [5].

Наказ про звільнення повинен бути вмотивованим, розгорнутим, законним у кожному конкретному випадку. Так, очевидним $\epsilon$, що:

1) звільняючи працівника за систематичне невиконання ним без поважних причин обов'язків, роботодавець зобов'язаний навести конкретні факти порушень та їх неодноразовий характер, відобразитипопередні стягнення, які булизастосованідо винного.Необхіднозробити саметак, адже для застосування саме такої підстави для накладення дисциплінарної санкції важливим $є$ не сам факт порушення трудової дисципліни, а наявність системи порушень, причому за кожен із проступків до працівника мали б застосовуватись заходи дисциплінарного чи громадського стягнення;

2) звільняючи працівника за прогул, відсутність працівника на робочому місці має бути зафіксованою. У процесі аналізу законодавства про працю ми дійшли висновку, що такими формами може бути акт чи табель обліку робочого часу, хоча це прямо й не передбачено нормами Кодексу законів про працю України [6];

3) звільняючи працівника за появу на роботі в нетверезому стані, у стані наркотичного або токсичного сп'яніння, роботодавець зобов'язаний зафіксувати факт перебування на роботі працівника в робочий час в нетверезому стані (у стані наркотичного або токсичного сп'яніння). Чітких вимог для таких випадків також не встановлено, тому припустимо, що підтвердження факту сп'яніння може бути зафіксоване складанням акту чи примусовою госпіталізацією з подальшим отриманням медичної довідки про стан особи;

4) звільняючи працівника за вчинення на місці роботи розкрадання (в тому числі дрібного) майна, як підстава використовується встановлений вирок суду, який набрав законної сили, чи постанова органу, до компетенції якого входить застосування заходів громадського впливу [6]. Разом із тим, видання наказу є не єдиним обов'язком роботодавця щодо звільнених осіб. Роботодавець у день звільнення зобов'язаний видати наказ під підпис працівника, а в разі відмови скласти відповідний акт, видати трудову книжку із записом про підставу звільнення та провести розрахунок відповідно до статей 116 та 117 Кодексу законів про працю України [6]. Також аналіз зазначених норм законодавства про працю засвідчив надання законодавцем можливості працівнику оскаржити звільнення. Саме тому дотримання дослідженої нами процедури звільнення гарантує роботодавцеві досягнення ним того результату, на який він розраховує, та уникнення додаткових витрат унаслідок позову звільненої особи.

\section{Список використаних джерел:}

1. Великий тлумачний словник сучасної української мови : словник / уклад. і голов. ред. В.Т. Бусел. Київ, Ірпінь : ВТФ «Перун», 2002. 1440 с.

2. Горшенев В.М. Способы и организационные формы правового регулирования в социалистическом обществе. Москва : Юрид. лит., 1972. 256 с. 2008. 384 c.

3. Щербина ВI. Трудове право України : підручник / за ред. В.С. Венедіктова. Київ : Істина,

4. Лежнєва Т.М. Функціональний аналіз санкцій загальної дисциплінарної відповідальності. Науковий вісник Херсонського державного університету. Серія Юридичні науки. Випуск 3-2. Том 2. 2015. С. 53-56.

5. Про затвердження Інструкції про порядок ведення трудових книжок працівників. Наказ Міністерства праці України, Міністерства юстиції України, Міністерства соціально- 
го захисту населення України від 29.07.1993 № 58 [Електронний ресурс]. Режим доступу: http://zakon2.rada.gov.ua/laws/show/z0110-93.

6. Кодекс законів про працю України. Закон України від 10.12.1971 № 322-VIII. Biдомості Верховної Ради УРСР від 17.12.1971 1971. Додаток до № 50.

7. Конституція України. Закон України від 28.06.1996 № 254к/96-ВР. Відомості Верховної Ради Украӥни (ВВР). 1996. № 30. с. 141.

8. Калужный С.А. Объяснение нарушителя трудовой дисциплины. Известие высших учебных заведений. Правоведение. 1986. № 6. С. 67-70.

УДК 349.2

DOI https://doi.org/10.32844/2618-1258.2019.5-2.20

ЧУМАЧЕНКО І.М.

\title{
ДО ПРОБЛЕМИ ВИЗНАЧЕННЯ ВИДІВ ПРОЦЕСУАЛЬНИХ ПРАВОВІДНОСИН У ТРУДОВОМУ ПРАВІ УКРАЇНИ
}

\begin{abstract}
У статті на основі аналізу наукових поглядів вчених відзначається, що залежно від галузі права правники по-різному підходять до класифікації процесуальних правовідносин. Розглянуто думки фахівців із галузі трудового права на окреслену проблематику. Запропоновано власне бачення щодо видів процесуальних правовідносин у трудовому праві України, однак при цьому відмічено, що здійснений у статті поділ правовідносин може змінюватись у процесі вдосконалення останніх. 3'ясовано, що питання вирішення колективних трудових спорів регулюються нормами, які визначені в Законі України «Про порядок вирішення колективних трудових спорів (конфліктів)». Відповідно до вказаного Закону під колективним трудовим спором необхідно розуміти розбіжності, що виникли між сторонами соціально-трудових відносин щодо: 1) встановлення нових або зміни наявних соціально-економічних умов праці та виробничого побуту; б) укладення чи зміни колективного договору, угоди; в) виконання колективного договору, угоди або окремих їх положень; г) невиконання вимог законодавства про працю. Зроблено висновок, що в юридичній літературі ще й досі не визначеного єдиного підходу щодо класифікації процесуальних правовідносин, саме тому на основі аналізу наукових поглядів вчених та норм чинного законодавства України запропоновано класифікувати дані правовідносини таким чином: 1) залежно від виду трудового спору: а) щодо вирішення індивідуальних трудових спорів. б) щодо вирішення колективного трудового спору; 2) залежно від суб'єкта, що вирішує трудовий спір; 3) залежно від цілей вирішення трудового спору: а) правовідновлюючі; б) каральні; в) компенсаційні; 4) залежно від мети, функцій та завдань процесуальних правовідносин: а) регулятивні (правовстановлюючі); б) охоронні; 5) з урахуванням структури змісту правовідносини можуть бути поділені на: прості та складні. Звісно, запропонована нами класифікація процесуальних правовідносин у трудовому праві не претендує на повноту та вичерпність, а здійснений нами поділ правовідносин може змінюватись у процесі вдосконалення останніх.
\end{abstract}

Ключові слова: правовідносини, прочесуальні правовідносини, трудове право Украӥни, вид, класифікації.

In the article, based on the analysis of scientific views of scientists, it is noted that, depending on the field of law, lawyers differently approach the classification of procedural legal relations. Opinions of experts in the field of labor law on the outlined problems

(C) ЧУМАЧЕНКО І.М. - доктор юридичних наук, доцент, професор кафедри цивільного права (Запорізький національний університет) 